\title{
Традиционные темы в эпическом репертуаре джангарчи Телтя Лиджиева
}

\section{Байрта Барбаевна Манджиева ${ }^{1}$}

\author{
${ }^{1}$ Калмыцкий научный центр РАН (д. 8, ул. И. К. Илишкина, 358000 Элиста, Российская \\ Федерация) \\ кандидат филологических наук, ученый секретарь, ведущий научный сотрудник \\ (iD) 0000-0002-5644-3340. E-mail: mbbairta@yandex.ru
}

\author{
(C) КалмНЦ РАН, 2020 \\ (C) Манджиева Б. Б., 2020
}

Аннотация. Введение. В статье рассматриваются традиционные темы в эпическом репертуаре джангарчи Телтя Лиджиева, одного из талантливых и самобытных джангарчи, исполнителя песен выдающегося рапсода XX в. Ээлян Овлы. Материальь. Среди записей калмыцкого фольклора, выполненных сотрудниками КНИИЯлИ (ныне КалмНЦ РАН) во время полевых экспедиций в 1960-1990-х гг., имеются аудиозаписи известного джангарчи Телтя Лиджиева. Запись осуществлена Н. Ц. Биткеевым во время фольклорной экспедиции по районам Калмыкии летом 1970 г. Целью настоящей работы является исследование поздней традиции «Джангара», бытовавшей во второй половине XX в., на материале сохранившихся записей эпического репертуара джангарчи Телтя Лиджиева. Результаты. Эпический репертуар Телтя Лиджиева как представителя школы Ээлян Овлы состоит из вступительной части (пролога оршл) и десяти песен. Телтя Лиджиев, несомненно, владел формульным языком, традиционными композиционными приемами, которые обеспечивали последовательность его повествования. Сказитель, зная все этапы каждой темы и технику составления формульных оборотов и самих формул, владея композиционными приемами, обретал некую определенную основу, на которой строил свое повествование. В песнях Телтя Лиджиева присутствуют такие традиционные темы эпического повествования, как: выбор богатыря; седлание коня; снаряжение богатыря; отправление в путь; преодоление пути; прибытие на пограничье; вхождение во дворец; поиск; богатырский поединок; пленение и клеймение; исцеление богатыря; возвращение; пир. Рассмотрение песен Телтя Лиджиева показало, что традиционные темы эпического повествования прочно сохранились в памяти джангарчи. Но, вместе с тем, необходимо отметить, что каждое исполнение уникально, джангарчи во время сложения эпического текста выбирает тот или иной путь трансляции, строит повествование по своему плану, используя традиционные слагаемые эпоса. Таким образом, джангарчи является носителем традиции, привнося новые элементы в исполнение эпических песен «Джангара».

Ключевые слова: эпос «Джангар», эпический репертуар, джангарчи, традиция, текст, песня, тема, герой, богатырь 
Благодарность. Исследование проведено в рамках государственной субсидии проект «Устное и письменное наследие монгольских народов России, Монголии и Китая: трансграничные традиции и взаимодействия» (регистрационный номер AAAА-А19-119011490036-1).

Для цитирования: Манджиева Б. Б. Традиционные темы в эпическом репертуаре джангарчи Телтя Лиджиева // Монголоведение. 2020. Т. 12. № 4. C. 668-678. DOI: $10.22162 / 2500-1523-2020-4-668-678$

UDC 398.22

DOI: $10.22162 / 2500-1523-2020-4-668-678$

\title{
Traditional Themes in the Epic Repertoire of Jangarchi Teltya Lidzhiev
}

\section{Bayrta B. Mandzhieva ${ }^{1}$}

\author{
${ }^{1}$ Kalmyk Scientific Center of the RAS (8, Ilishkin St., Elista 358000, Russian Federation) \\ Cand. Sc. (Philology), Scientific Secretary, Leading Research Associate \\ iD 0000-0002-5644-3340. E-mail: mbbairta@yandex.ru
}

(C) KalmSC RAS, 2020

(C) Mandzhieva B. B., 2020

\begin{abstract}
Introduction. The article examines traditional themes in the epic repertoire of jangarchi Teltya Lidzhiev, a most talented and original jangarchi, and a performer of songs of the $20^{\text {th }}$-century prominent rhapsode Eelyan Ovla. Materials. The recordings of Kalmyk folklore made by associates of the Kalmyk Research Institute of Language, Literature and History (present-day KalmSC RAS) during field expeditions in the 1960s - 1990s contain one by the famous jangarchi Teltya Lidzhiev. The recording was made by N. Ts. Bitkeev during a folklore research trip across districts of Kalmykia in the summer of 1970. Goals. At present, thanks to the preserved records of the epic repertoire of jangarchi Teltya Lidzhiev, there is an opportunity to explore the late tradition of the Jangar which existed in the second half of the $20^{\text {th }}$ century. Results. The epic repertoire of Teltya Lidzhiev who was representing Eelyan Ovla's school consists of an introductory part, a prologue (Kalm. orshl) and ten songs. Teltya Lidzhiev undoubtedly possessed a formulaic language, traditional compositional techniques that ensured the consistency of his narration. The storyteller had carefully elaborated all the stages of each theme and adopted the technique of drawing up formulaic turns and the formulas themselves, as well as compositional ones, to acquire a certain structured basis to build his narrative on. Teltya Lidzhiev's songs comprise traditional themes of epic narration, such as selection of a hero, saddling of a horse, munitioning of the hero, departure, adversities of the path, arrival in borderlands, entering of the palace, searches, heroic duel, capture and branding, healing of the hero, return, feast. The examination of Teltya Lidzhiev's songs shows that the traditional epic themes were firmly preserved in the jangarchi's memory. But at the same time, it should be noted that each performance is unique: a jangarchi constructs his epic text and chooses one or another way of retransmission, the speed of clustering poems during a performance prompted the use of certain traditional formulas but one would certainly build his narrative according to a definite plan of his own. Thus, jangarchi is both a bearer of the tradition and an individual singer.
\end{abstract}

Keywords: Jangar epic, epic repertoire, jangarchi, tradition, text, song, theme, hero 


\section{Монголоведение • Mongolian Studies • 2020 ๑ T. 12 • № 4}

Acknowledgements. The reported study was funded by government subsidy — project name 'Oral and Written Heritage of Mongolic Peoples of Russia, Mongolia and China: CrossBorder Traditions and Interactions' (state reg. no. AAAA-A19-119011490036-1).

For citation: Mandzhieva B. B. Traditional Themes in the Epic Repertoire of Jangarchi Teltya Lidzhiev. Mongolian Studies (Elista). 2020.Vol. 12. No. 4. Pp. 668-678. (In Russ.). DOI: $10.22162 / 2500-1523-2020-4-668-678$

\section{Введение}

Героический эпос «Джангар» представляет собой вершинное достижение устного творчества калмыцкого народа, свидетельство высокого уровня развития его духовной культуры. В том, что эпос сохранен до наших дней и эпическая традиция жива, - заслуга сказителей-джангарчи, бережно передававших из поколения в поколение его текст, идеи и образы. «В фольклорной традиции калмыков сказитель является носителем и хранителем самых разнообразных знаний, опыта, духовных ценностей и традиций. Имя сказителя окружено легендами о происхождении дара эпического повествователя-джангарчи. Изучение биографии сказочников-джангарчи позволило выявить сказительские школы - это династия джангарчи, которые передают свое искусство и репертуар» [Басангова 2018: 31].

Одним из талантливых и самобытных джангарчи является Телтя Лиджиев (1906-1970), исполнитель эпического репертуара выдающегося рапсода ХХ в. Ээлян Овлы. Среди записей калмыцкого фольклора, выполненных сотрудниками КНИИЯЛИ (ныне - КалмНЦ РАН) во время полевых экспедиций в 1960-1990-х гг., имеются аудиозаписи известного джангарчи Телтя Лиджиева. Запись осуществлена Н. Ц. Биткеевым во время фольклорной экспедиции по районам Калмыкии летом 1970 г. В настоящее время, благодаря сохранившимся записям эпического репертуара джангарчи Телтя Лиджиева, нам представилась возможность исследовать позднюю традицию «Джангара», бытовавшую во второй половине ХХ в.

Настоящее исследование посвящено рассмотрению традиционных тем эпических песен джангарчи Телтя Лиджиева, бытовавших во второй половине $\mathrm{XX}$ в. Джангарчи Телтя Лиджиев, несомненно, владел формульным языком, традиционными композиционными приемами, которые обеспечивали последовательность его повествования. В отечественной фольклористике исследователями уделялось и уделяется наибольшее внимание изучению формульной природы языка традиционной эпической поэзии. Сложению эпической песни способствовало широкое использование идентично построенных, стилистически однотипных описаний и ситуаций, которые, по определению М. Пэрри [Рarry 1930: 80] и А. Лорда [Лорд 1994: 83], называются «темами». А. Ф. Гильфердинг, изучая технику русского былинного стиха, сделал вывод о присутствии в эпосе «типических мест» (loci communes), «которые, в отличие от „мест переходных ${ }^{е}$, с определенным сюжетом связанных, предстают в одном и том же облике в самых различных былинах» [Онежские былины 1949: 57]. П. Д. Ухов при анализе «типических мест» в былинах также использует термин «типическая формула» и практически не отделяет их друг от друга [Ухов 1957: 134]. По мнению П. А. Гринцера, «темы, принадлежат принципиально иной сфере эпической повествовательной техники, и по отношению к ним 
формулы в своей совокупности могут рассматриваться как необходимый для них «строительный материал» [Гринцер 1978: 17-18]. Безусловно, запоминание эпических песен огромных размеров, при отсутствии их письменного текста, конечно, невозможно, и сказитель не помнит их, а скорее знает принципы и способы их сложения.

\section{О джангарчи Телтя Лиджиеве}

Джангарчи Телтя Лиджиев родился 22 декабря 1906 г. в поселке Енотаевка Юстинского района Калмыцкой АССР в семье бедняка. В раннем детстве, оставшись сиротой, Телтя пас скот местного богача. Работал здесь и Окон Бадмаев, знаток песен «Джангара» из репертуара Ээлян Овлы. Впервые услышав пение джангарчи, Телтя был впечатлен эпосом «Джангар». При каждом исполнении он старался запоминать репертуар сказителя. К сожалению, ему не всегда удавалось слушать «Джангар», но все же украдкой, а иногда и через стенку кибитки, мальчик запоминал песни. Запомнив ритмичное исполнение эпических стихов, Телтя в степи громко пересказывал услышанную песнь. Так, к двенадцати годам, благодаря хорошей памяти, Телтя Лиджиев усвоил большую часть песен «Джангара» из репертуара Окона Бадмаева [Биткеев 2001: 98-99], которому в свое время помог овладеть мастерством джангарчи Окон Шараев - племянник Ээлян Овлы [История калмыцкой литературы 1981: 161]. Таким образом, эпический репертуар Телтя Лиджиева составляют известные песни «Джангара» в исполнении великого рапсода Ээлян Овлы [Манджиева 2019а: 54].

\section{О репертуаре джангарчи Телтя Лиджиева и эпической школе Ээлян Овла}

Эпический репертуар Телтя Лиджиева как представителя школы Ээлян Овлы состоит из вступительной части - Орил («Пролог») и десяти песен:

1) «Алтн Чееж Жаңһр хойрин бәәр бәрлдсн бөлг» («Песнь о поединке Алтан Чеджи и Джангара»),

2) «Буурл һалзн мөртә Бульңһрин көвүн Догшн Хар Санлын бөлг» («Песнь о Булингира сыне - Смуглом Строгом Санале, ездящем на скакуне Бурал Галзан»),

3) «Хоңһрин гер авлһна бөлг» («Песнь о женитьбе Хонгора»),

4) «Орчлңгин сәәхн Мингьян түрг хаани түмн шар-цоохр агт көөгсн бөлг» («О том, как Прекраснейший в мире Мингъян пригнал табун золотистых скакунов»),

5) «Орчлңгин сәәхн Мингьян күчтә Күрмн хааг әмдәр кел бәрж ирсн бөлг» («Пленение Прекраснейшим в мире Мингъяном могучего Кюрмен-хана»),

6) «Арслңгин Арг Улан Хоңһр, Арг Манзиин буурлта, Әәх Догшн Маңна хаанла бәәр бәрлдгсн бөлг» («Песнь о поединке льва[-богатыря] Улан Хонгора Прекрасного с грозным ханом Догшин Мангна»),

7) «Дуутхулын ач, Дуутын көвүн Аля Монхля Жаңһрин түмн нәәмн миңһн цусн зеерд агт көөгсн бөлг» («Песнь о том, как внук Дутхулы, сын Дууты Аля Монхля пригнал восьмидесятитысячный табун золотистых скакунов»),

8) «Баатр Хар Жилһнлә Арслңгин Арг Улан Хоңһр бәрлдгсн бөлг» («О поединке Алого Хонгора с богатырем Хара Джилганом»),

9) «Күнд һарта Саврин бөлг» («Песнь о Саваре Тяжелоруком»), 
10) «Хошун Улан, баатр Жилһн, Аля Шоңхр һурвна бөлг» («Песнь о трех богатырях Хошун Улане, Джилгане, Аля Шонхоре»). Кроме эпического репертуара Ээлян Овлы, он усвоил еще две крупные песни эпоса «Джангар» «Догшн Шар Гүргү маңһс хааг Дуут Улан Шовшур дөрәцүлгсн бөлг» («О победе Славного Алого Шовшура над Свирепым ханом мангасов Шара Гюргю»), принадлежащей к Малодербетовскому циклу (1862 г.), и песнь Багацохуровского цикла (1857 г.) «Дуут богд Жаңһр догшн Хар Кинесиг дөрәцүлгсн бөлг» («О том, как славный богдо Джангар свирепого Хара Кинеса покорил») от джангарчи Бадмин Менкенасана (1879-1944) [НА КалмНЦ РАН. Ф. 16. Оп. 1].

Джангарчи Телтя Лиджиев относится к традиционной эпической школе Ээлян Овлы, которая не изменяла сюжеты песен [Биткеев 1982: 102]. «Ээлян Овла был наследником целой династии джангарчи, которые относились к традиционной консервативной школе. Как и все известные калмыцкие рапсоды, эпическим языком Овла овладел в раннем возрасте и «Джангар» перенял уже в сложившемся виде. Джангарчи Ээлян Овла и его последователи Окон Шараев, Окон Бадмаев, Телтя Лиджиев старались сохранить первозданный текст, потому как эпические певцы считали «Джангар» сакральным памятником, не подлежащим трансформации. Для представителей этой школы одной из главных установок было исполнять эпос так, как усвоили его от предшественников» [Манджиева 2019б: 84].

\section{Традиционные темы в прологе и песнях джангарчи Телтя Лиджиева}

Как известно, фольклорный текст в процессе многократного устного воспроизведения всегда варьируется. В резерве памяти эпического певца хранится традиционный и стандартизированный набор сюжетов, стилистических и композиционных приемов, которые широко использовались при исполнении эпоса, при этом каждое исполнение было неповторимо. Одна и та же тема не могла быть представлена одинаково не только у разных, но и у одного и того же сказителя. Систематический подход к изучению записей джангарчи, принадлежавших к одной эпической школе, имеет немаловажное значение «для изучения коллективного и личного в передаче эпоса» [Гацак 1971: 45].

Сравнительно-сопоставительный анализ экспозиционной части и эпических песен Телтя Лиджиева с односюжетными песнями цикла Ээлян Овлы дает нам возможность увидеть каким образом создается тема, как происходит её амплификация (от фр., англ. amplification 'увеличение') и редукция (от лат. reducire 'сокращение'), как темы соединяются между собой, какова степень сохранности текста.

Джангарчи, зная все этапы песни, имеет некий определенный план, по которому он строит свое повествование. Так, планом пролога у Ээлян Овлы являются темы, стоящие в определенном порядке:

1. Биография Джангара, описание его подвигов;

2. Описание страны;

3. Совет богатырей;

4. Описание построения дворца;

5. Описание знамени;

6. Описание хатун;

7. Описание пира. 
Тема «Описание пира» в свою очередь подразделяется на подтемы и состоит из более мелких частей, а именно подтем а) Мингияна; б) Алтан Чеджи; Улан Хонгора; в) Гюзян Гюмбе; г) Савара; д) Санала. Описание пира завершается представлением стариков, старушек, замужних женщин и молодиц, сидящих полукругами на пиру [Жаңһр, 1 1978: 376-383].

Пролог у Телтя Лиджиева состоит из следующих тем:

1. Биография Джангара, описание его подвигов;

2. Совет богатырей;

3. Описание построения дворца;

4. Описание знамени;

5. Описание страны;

6. Описание хатун;

7. Описание страны;

8. Описание пира.

В свою очередь, тема «Описание пира» также состоит из подтем-представлений богатырей: а) Алтан Чеджи; б) Улан Хонгора; в) Савара; г) Санала; д) Гюзян Гюмбе; е) Мингияна. Описание пира завершается также представлением стариков, женщин и молодиц, сидящих полукругами на пиру [НА КалмНЦ РАН. Ф. 16. Оп. 1. Фонозаписи. Кассета № 97].

В сравнении с прологом Ээлян Овлы в тексте Телтя Лиджиева мы наблюдаем перестановки тем, а также композиционные изменения. Так, после представления биографии Джангара и описания его подвигов в аудиозаписи идет пауза. Возможно, джангарчи выбирал в памяти следующую тему, и, в отличие от предшественника, он выбрал не 'описание страны', а 'совет богатырей' и взаимосвязанные с ней темы — 'построение дворца' и 'описание знамени'. Тема 'описание страны' у Телтя Лиджиева разбивается на две части: между этими частями джангарчи вставляет тему 'описание ханши'. Сравнение тем в прологе Телтя Лиджиева показывает, что джангарчи во время сложения эпического текста выбирает тот или иной путь трансляции. Во время исполнения песни рапсоду приходилось быстро складывать стихи, поэтому он использовал традиционные формулы, но строил повествование по своему определенному им плану. Таким образом, джангарчи является носителем традиции, но привносит в исполнение эпических песен некую новизну, своего рода творческое начало, тем самым создавая новое произведение.

В песнях Телтя Лиджиева присутствуют такие традиционные темы эпического повествования, как: выбор богатыря; седлание коня; одевание-снаряжение богатыря; отправление в путь; преодоление пути; прибытие на пограничье; вхождение во дворец; поиск; богатырский поединок; пленение и клеймение; исцеление богатыря; возвращение; пир.

Тема «выбора богатыря» в песне «Дуутхулын ач, Дуутын көвүн Аля Монхля Жаңһрин түмн нәәмн миңһн цусн зеерд агт көөгсн бөлг» («Песнь о том, как внук Дутхулы, сын Дууты Аля Монхля пригнал восьмидесятитысячный табун золотистых скакунов») развертывается стремительно: Джангар, узнав об угоне восьмидесятитысячного табуна, решает незамедлительно пуститься в погоню:

— Агтан көөлгна гисн / Алдршго му нерн, / Әмн болсн / Арвн хойр бодњ минь,

/ Ардасни некий! - гиж⿻ән. '- Позволить угнать свой табун / Несмываемым 


\section{Монголоведение • Mongolian Studies • 2020 ๑ T. 12 • № 4}

позором станет для нас, / Как жизнь, дорогие мои двенадцать вепрей[-богатырей], / Погонимся, отберём! — так сказал’ [НА КалмНЦ РАН. Ф. 16. ОП. 1. Фонозаписи. Кассета № 98].

Тема «выбора богатыря» в песне «Буурл һалзн мөртә Бульңһрин көвүн Догшн Хар Санлын бөлг» («Песнь о Булингира [сыне] - Смуглом Строгом Санале, ездящем на скакуне Бурал Галзан») мотивирована тем, что вражеский хан Зан Тайджи готовится к захвату Бумбы, поэтому Джангар возлагает на богатыря Санала исполнить трудную миссию посла:

- Булиңзһрин Догшн Хар Санл, / Чамаһан нег хәр һазрт зарн гижсзнәв. / Зархларн, Зан Тәәжс хаани нутгт күрч, / Дән болхла, дәәһинь соңсад, / Эл болхла, ээлинь соңсад ирич, - гив. '- Булингира [сын] - Смуглый Строгий Санал мой, / В чужие земли отправить тебя хочу. / В страну хана Зан Тайджи отправляю. / Если мира он хочет, услышь о мире от него, / Если войны он хочет, услышь о войне от него, — повелел’ [НА КалмНЦ РАН. Ф. 16. Оп. 1. Фонозаписи. Кассета № 98].

Завязкой сюжета песни «Арслңгин Әср Улан Хоңһр Арг Манзиин буурлта, Әәх Догшн Маңна хаанла бәәр бәрлдгсн бөлг» («Песнь о поединке льва[-богатыря] Улан Хонгора Прекрасного с грозным ханом Догшин Мангна») является появление в разгар пира во дворце Джангара посланца враждебного хана Догшин Мангна хана с ультимативным требованием пяти «вещей»: аранзала Зерде, хатун Шавдал, Буурал Галзана, богатыря Мингияна и богатыря Улан Хонгора. В песне Телтя Лиджиева выбор богатыря для поездки реализован «самовыдвижением» богатыря Хонгора, потому что в предъявленном ультиматуме задета честь богатыря Хонгора. Формула Хәр haзpm оджс / Aphcн түләнә күн болюс заргдхин ормд, / Әгр хар булгин көвәд / Ааһ иусан асхлинав! 'В чужой стране / Чем быть в услужении, / Пусть лучше у чистого источника прольётся кровь!' [НА КалмНЦ РАН. Ф. 16. Оп. 1. Фонозаписи. Кассета № 98] выражает решимость героя выступить навстречу противнику. В другой песне эпического репертуара Телтя Лиджиева «Күнд һарта Саврин бөлг» («Песнь о Саваре Тяжелоруком») «самовыдвижение» богатыря мотивировано несогласием Хонгора с предъявленным Джангару ультиматумом Килган-хана отдать ему три «вещи»: хатун Шавдал, аранзала Зерде и богатыря Мингияна. Требуемые ханом-антагонистом «вещи» являются сокровищами Бумбы, символизируют ее государственность: хатун Шавдал — супруга Джангар-хана: отдать ее в услужение вражескому хану равносильно потере своей власти; аранзал Зерде - скакун Джангара: если хан теряет свою власть, то и скакун ему незачем, богатырь Мингиян - прекраснейший из богатырей, распорядитель на пиру: потерять его означает не быть пиру, т. е. Бумба опустеет, а ханство Килган-хана станет еще могущественнее [НА КалмНЦ РАН. Ф. 16. Оп. 1. Фонозаписи. Кассета № 98]. В ответ на ультиматум Килган-хана богатырь Хонгор выразил готовность сразиться с противником:

Олн Жаңһрин нутг / Бүрн төгс бәәһәд / КүҮнә һарт орна гидг. Уга! / Килин хаандан оч кел, / Бәәр бәрлдий гиж, / Әср Улан Хоңһһр келүлв гижс кел», — гив. ' «Многочисленная страна Джангара / В благополучии пребывает / Быть полоненными. Нет! / Передай Килган-хану, / Будем биться, Улан Хонгор так пере- 
дал, скажи!» — сказал’ [НА КалмНЦ РАН. Ф. 16. Оп. 1. Фонозаписи. Кассета № 98].

Формульное выражение: Күүкн күризг һалзнм / Тохюс өгтн! [НА КалмНЦ РАН. Ф. 16. Оп. 1. Фонозаписи. Кассета № 98] обозначает начало темы «седлание коня» в песне «Күнд һарта Саврин бөлг» («Песнь о Саваре Тяжелоруком»), которое является важным этапом подготовки к походу. В эпосе «Джангар» с неизменной полнотой и любованием описываются принадлежности конского снаряжения. Необходимо заметить, что после формульного выражения, обозначающего начало темы «седлание коня» Телтя Лиджиев, в отличие от односюжетной песни Ээлян Овлы, вставляет тему «одевание-снаряжение богатыря», а затем дает детальное описание седлания:

Күрнъг Һалзн күлгиг [көтләд ирв.] / Хала мөңзн хазариг / Дунчһар дууна һазрас / Хавлн өмскв. / Күрңзг Һалзн күлгиг / Йендр мөнзгн делтр тәвәд, / Дегц зурһан давхр тохм тәвәд, / Наәш хар эмәл тәвәд, / Көндлиз мөнцгн көвчг тәвәд / Ке шар-иоохр олнцгин захар / Келкә найн нәәмн һорькиг / Хорни шүүһәр элкәдн татв. / Зура тални / Зун нәәмн хонх зүүһәд ирв, / Күзүн тални бәәдг / Күрл нәәмн хонх зүүһдд ирв. 'Кобылицу Кюрюнг Галзан он привел. / Серебристую узду / С дальнего расстояния / Набросив, надел, / На кобылицу Кюрюнг Галзан / Расшитый серебром подпотник набросил, / Разом шестислойный потник набросил, Широкое, как наковальня, седло положил, / Седельную подушку, расшитую серебром, положил, / По краям украшающих жёлто-пёстрых тебеньков / Соединённые восемьдесят восемь пряжек / С силой затянул, / На крупе / Сто восемь бубенчиков подвесил, / На шею ей / Бронзовых восемь бубенчиков подвесил' [НА КалмНЦ РАН. Ф. 16. Оп. 1. Фонозаписи. Кассета № 98].

Тема «одевание-снаряжение богатыря» в песнях Телтя Лиджиева строится по выработанной схеме:

Күндн hарта Савр / Дәәни олн хувиан / Давхр-давхр өмсв. / Миимин улан һосан өмсәд, / Дөнн иарин арсар һадрлгсн, / Һунн иарин арсар дотрлгсн, / Һо шүҮһәр шахсн, / Хорта моһан зо дуралһсн, / Махн болдар альхлгсн, / Төмр болдар товчлгсн, / Улан зандар ишлгсн, / Зала торһар салдрлгсн / Әәрстин хар елдңгиг / Барун һартан атхв. 'Савар Тяжелорукий / Боевые доспехи свои / Друг на друга надев, / Мягкие красные сапоги надев, / Из шкуры четырёхлетнего вола оплётку имеющую, / Из шкуры трёхлетнего вола стержень имеющую, / Словно выдавливали сок, такую тугую, / С плетением, схожим со змеиной кожей, / С пластиной из чистой стали, / С шишаком на конце из крепкого железа, / С рукоятью из молодого сандала, / С шелковистой ременной петлёй / Грозную тугую плеть / В правой руке сжал' [НА КалмНЦ РАН. Ф. 16. Оп. 1. Фонозаписи. Кассета № 98].

«Личное оружие наряду с конем - основной „знак“ богатыря; оно характеризует героя через свое развернутое определение-характеристику <..> вооружение богатыря - венец подготовки» [Кичиков 1992: 257]. Перед отправкой Савара в боевой поход богатыри отдают ему свое личное оружие:

Эзн нойна / Арслизгин Арг Улан Хоңһһннь / Далн негн алд билгин шар-болд Үлдән / Хәр һазрт кергтә зер-зев гижс / Санлдан өгв. / Күнд һарта Савр / Найн 


\section{Монголоведение • Mongolian Studies • 2020 ๑ T. 12 • № 4}

нег алд әәв балтан / Хәр һазрт кергтә гижс / Санлдан өгв. / Гүзән Гүмб ахр хар ханж⿻алан / Хәр һазрт кергтә, / Зүүжс йов гижс / Санлдан өгв. 'Владыки, нойона / Лев[-богатырь] Улан Хонгор Прекрасный / В семьдесят одну сажень разящий свой меч / Со словами: - В чужой стороне пригодится такое / Саналу отдал. Тяжелорукий Савар / В восемьдесят одну сажень секиру свою / Со словами: В чужой стороне пригодится такое / Саналу отдал / Гюзян Гюмбе короткий черный свой кинжал, / Со словами: - В чужой стороне пригодится такое / Саналу отдал’ [НА КалмНЦ РАН. Ф. 16. Оп. 1. Фонозаписи. Кассета № 98].

Традиционная тема «богатырский поединок» в героическом эпосе калмыков занимает важное место. В песне «Арслңгин Арг Улан Хоңһр әмндән күрн йовж, арг Манзн Буурлта Әәх Догшн Маңна хааг хораж, эзн, богд Жаңһрт орулж өгсн бөлг» («Песнь о том, как лев[-богатырь] Улан Хонгор Прекрасный, едва не лишившись жизни, могучего Манзан Бурала имеющего грозного хана Догшин Мангна уничтожив, [владения его] властителю, богдо Джангару подчинил») джангарчи Ээлян Овлы богатырь Улан Хонгор сражается с вражескими богатырями Шовто Хара и Нярин Уланом, вслед за ними и с сорока двумя богатырями. Данная тема в песне «Арслңгин Арг Улан Хоңһp, Арг Манзиин буурлта, Әәх Догшн Маңна хаанла бәәр бәрлдгсн бөлг» («Песнь о поединке льва[-богатыря] Улан Хонгора Прекрасного с грозным ханом Догшин Мангна») Телтя Лиджиева изображена в несколько измененном виде: так, Хонгор, выпросив у Мингияна скакуна аранзала Зерде, вступает в схватку с посланцем Мангна-хана богатырем-антагонистом Нарин Уланом. Расправившись с Нарин Уланом, Хонгор вступает в единоборство с ханом Догшин Мангна. Описание богатырского поединка дается в гиперболических тонах. Эта тема является кульминацией песни. Именно в описании сражения эпическое повествование достигает наивысшего накала. Рапсод, изображая битву Хонгора в окружении вражеского войска, всецело завладевает вниманием слушателей, которые напряженно следят за ходом событий.

Песнь завершается описанием пира, где богатыри Джангара, захмелев от прозрачной apзы, выражают готовность к новым походам и битвам с врагом во славу Бумбы. Особое место в композиции эпоса занимает сцена пира в ханском дворце. В «Джангаре» пир является как отправной точкой, так и заключительным звеном эпического повествования.

\section{Заключение}

Песни эпического репертуара джангарчи Телтя Лиджиева от начала до конца повествования разработаны как напряженное противоборство сторон, как борьба с могучим, уверенным в своих силах противником, и конечная победа воспринимается как победа духа — как моральное превосходство Джангар-хана и богатырей Бумбы над жестоким и свирепым захватчиком.

Таким образом, рассмотрение песен Телтя Лиджиева показало, что традиционные темы эпического повествования прочно сохранились в памяти джангарчи. До начала исполнения, запланировав все этапы каждой темы, владея техникой составления формульных оборотов, самими формулами, композиционными приемами, певец находил свой путь в построении и исполнении эпи- 
ческой песни. Но, вместе с тем, необходимо отметить, что каждое исполнение уникально, джангарчи во время сложения эпического текста выбирает тот или иной путь трансляции, строит повествование по своему определенному им плану, используя традиционные слагаемые эпоса. Таким образом, джангарчи является носителем традиции, привнося свое в исполнение песен как в само построение текста, так и в стилистику эпических песен. «Сказитель не сознательный иконоборец, он - художник, творящий в рамках традиции. Его традиционный стиль одновременно индивидуален, и мы можем отличить песни одного сказителя от песен другого, располагая одним лишь текстом и не зная ни музыки, ни особенностей пения» [Лорд 1994: 15].

\section{Источники}

Жаңһp, 11978 - Жаңһp. Хальмг баатрлг дуулвр (25 бөлгин текст: 1-2 боть) (= Джангар. Калмыцкий героический эпос (тексты 25 песен)) / сост. А. Ш. Кичиков; ред. Г. И. Михайлов. Т. 1. М.: Наука, ГРВЛ, 1978. 441 с.

НА КалмНЦРАН - Научный архив КалмНЦРАН. Ф. 16. Оп. 1. Фонозаписи эпических песен репертуара Телтя Лиджиева (кассеты № 97-98).

\section{Sources}

Jangar: A Heroic Epic of the Kalmyks. Texts of 25 Epic Songs. A. Kichikov (comp.); G. Mikhaylov (ed.). Vol. 1. Moscow: Nauka, GRVL, 1978. 441 p. (In Kalm.)

Kalmyk Scientific Center of the RAS, Scientific Archives. Coll. 16. Cat. 1. Audio recordings of epic songs from Teltya Lidzhiev's repertoire (Cassettes no. 97-98). (In Kalm.)

\section{Литература}

Басангова 2018 - Басангова Т. Г. Сказительство калмыков // Вестник Северо-Восточного федерального университета имени М. К. Аммосова. Серия Эпосоведение. 2018. № 2 (10). С. 31-39.

Биткеев 1982 - Биткеев Н. Ц. Поэтический стиль джангарчи («школа» Ээлян Овла) // Эпическая поэзия монгольских народов (исследования по эпосу). Элиста: [б. и.], 1982. C. 95-105.

Биткеев 2001 - Биткеев Н. Ц. Джангарчи. Элиста: АПП «Джангар», 2001. 448 с.

Гацак 1971 - Гацак В. М. Эпический певец и его текст // Текстологическое изучение эпоса. М.: Наука, 1971. С. 7-46.

Гринцер 1978 - Гринцер П. А. Стилистическое развертывание темы в санскритском эпосе // Памятники книжного эпоса. Стиль и типологические особенности. М.: Наука, ГРВЛ, 1978. С. 16-48.

История калмыцкой литературы 1981 - История калмыцкой литературы. В 2-х т. Т. 1. Дооктябрьский период / под ред. Г. И. Михайлова, А. Ш. Кичикова, Н. Б. Сангаджиевой и др.; отв. ред. Г. И. Михайлов, Р. А. Джамбинова. Элиста: Калм. кн. издво, 1981.336 с.

Кичиков 1992 - Кичиков А. Ш. Героический эпос «Джангара»: сравнительнотипологическое исследование памятника. М.: Наука, Вост. лит., 1992. 320 с.

Лорд 1994 - Лорд А. Б. Сказитель. М.: Вост. лит., 1994. 368 с.

Манджиева 2019a - Манджиева Б. Б. Текстология пролога эпоса «Джангар»: сравнительный анализ разновременных записей джангарчи Ээлян Овла и Телтя Лиджиева // Новый филологический вестник. 2019. № 49. С. 51-64.

Манджиева 20196 - Манджиева Б. Б. Сохранность эпической песни «Джангара» во времени: текст «певца-учителя» и «певца-ученика» // Новый филологический вестник. 2019. № 51. С. 82-97. 
Онежские былины 1949 - Онежские былины, записанные А. Ф. Гильфердингом летом 1871 года. В 3 т. Т. 1. М.; Л.: Изд-во АН СССР, 1949. 669 с.

Ухов 1957 - Ухов П. Д. Типические места (loci communes) как средство паспортизации былин // Русский фольклор: Материалы и исследования. Вып. 2. М.; Л.: Изд-во АН CCCP, 1957. C. 129-154.

Parry 1930 - Parry M. Studies in the epic technique of oral verse-making // Parry M. Homer and Homeric Style. Harvard Studies in Classical Philology. 1930. Vol. 41. Pp. 80-84.

\section{References}

Basangova T. G. Storytelling of Kalmyks. Vestnik of North-Eastern Federal University. Series 'Epic Studies'. 2018. No. 2 (10). Pp. 31-39. (In Russ.)

Bitkeev N. Ts. Poetic style of the jangarchi: 'school' of Eelyan Ovla. In: Epic Poetry of Mongolic Peoples. Studies of Epic Traditions. Elista, 1982. Pp. 95-105. (In Russ.)

Bitkeev N. Ts. The Jangarchi. Elista: Dzhangar, 2001. 448 p. (In Russ.)

Gatsak V. M. Epic rhapsode and his text. In: Textual Studies of Epic. Moscow: Nauka, 1971. Pp. 7-46. (In Russ.)

Grintser P. A. Stylistic development of a theme in the Sanskrit epic. In: Printed Epic Monuments. Style and Typological Features. Moscow: Nauka, GRVL, 1978. Pp. 16-48. (In Russ.)

Kichikov A. Sh. Heroic Epic of Jangar: A Comparative Typological Study of the Monument. Moscow: Nauka, Vostochnaya Literatura, 1992. 320 p. (In Russ.)

Lord A. B. The Taleteller. Moscow: Vostochnaya Literatura, 1994. 368 p. (In Russ.)

Mandzhieva B. B. Integrity of one "Dzhangar" epic song across time: the text of the "rhapsode teacher' and that of his 'rhapsode student' revisited. The New Philological Bulletin. 2019. No. 51. Pp. 82-97. (In Russ.)

Mandzhieva B. B. Textology of the prologue to the "Dzhangar" epic: a comparative analysis of multi-temporal recordings from the dzhangarchis - Eelyan Ovla and Teltya Lidzhiev. The New Philological Bulletin. 2019. No. 49. Pp. 51-64. (In Russ.)

Mikhaylov G. I., Dzhambinova R. A. (eds.) History of Kalmyk Literature. In 2 vols. Vol. 1: Pre-October Period. Elista: Kalmyk Book Publ., 1981. 336 p. (In Russ.)

Onega Bylinas Recorded by A. F. Hilferding in the Summer of 1871. In 3 vols. Vol. 1. Moscow, Leningrad: USSR Academy of Sciences, 1949. 669 p. (In Russ.)

Parry M. Studies in the epic technique of oral verse-making. In: Parry M. Homer and Homeric Style. Harvard Studies in Classical Philology. 1930. Vol. 41. Pp. 80-84. (In Eng.)

Ukhov P. D. Russian bylinas: loci communes as a passportization means. In: Russian Folklore. Materials and Studies. Moscow, Leningrad: USSR Academy of Sciences, 1957. Vol. 2. Pp. 129-154. (In Russ.) 